\title{
Analysis of Science Process Skills through Blended Learning in Science Subjects
}

\author{
Ari Ambarwati Umisaroh ${ }^{1 凶}$ \\ ${ }^{1}$ Sebelas Maret University, Solo, Centra Java, Indonesia, \\ $\bowtie$ email: ambarari19@gmail.com
}

\section{Received: \\ 18 February \\ 2022 \\ Revised: \\ 25 February \\ 2022 \\ Accepted: \\ 26 February \\ 2022 \\ Published: \\ 02 August 2022}

\begin{abstract}
This study aimed to determine the implementation of science process skills through blended learning during the Covid-19 pandemic. Blended learning is a structured learning process between face-to-face learning and online learning that is carried out separately or has its own time. The research method used is a qualitative approach. Data collection techniques using observation, interviews, and documentation. The main instrument in data collection is the researcher himself, for the auxiliary instruments, are observation guidelines, interview guidelines, and documentation. The data analysis procedure went through 3 stages namely 1) data reduction, 2) data exposure, and 3) conclusion drawing and verification. Data validity uses source and method triangulation by comparing data information obtained from interviews, observations and documentation. The subjects of this study were grade IV students, totaling 15 children. The results of data analysis show that the implementation of science process skills through blended learning during the Covid 19 pandemic can both help students and teachers in facilitating learning, and the results of the analysis of science process skills during the Covid 19 pandemic seem successful and have a good effect on students. The results of this study can be used as input and consideration for other researchers to conduct research with other science process skills analysis variables.
\end{abstract}

Keywords: Covid; Blended Learning; Science Process Skills; Teaching Method.

\section{INTRODUCTION}

This pandemic has had many negative impacts on the lives of the Indonesian people. The most prominent thing is the economy, which has experienced a decline in the last few months, thus threatening the welfare of the Indonesian people. The bad state of the economy certainly does not only have an impact on society but many other aspects. The condition of Indonesian education is also an important spotlight for the government and the community. With government policies in the form of recommendations for social distancing and reducing crowding to suppress the spread of Covid-19, this will certainly have a huge impact on the world of education. As it is known that the world of education in Indonesia still cultivates face-to-face learning or direct learning. However, this has been highly considered to be applied during the 
current pandemic. Since the spread of Covid-19 in Indonesia, all educational institutions in Indonesia have held online learning, which is in the form of internetbased interactive learning that is applied as a tool or media in the teaching and learning process during the pandemic.

Based on the explanation above, there are still many challenges and obstacles in the distance learning process during this pandemic. So a more effective and efficient learning concept is needed to support learning success during this pandemic. Blended learning can be alternative learning to reduce problems in online learning (see Destika, 2022; Herlisya \& Wiratno, 2022; Nurchurifiani \& Zulianti, 2021; Sagita, 2021a, 2021b; Sitohang et al., 2021; Sulastri et al., 2022). In general, Blended Learning is learning that combines face-to-face and online learning by using various learning methods that combine face-to-face meetings with online teaching to improve learning skills. Blended Learning can be an ideal lesson to be applied during this pandemic, because it offers two methods that are in accordance with the idea of an education system during a pandemic put forward by the Ministry of Education and Culture Nadiem Makarim.

Science learning has not yet touched the development of science process skills optimally. Suastra's research in Aziz (2012) explains that the low level of science learning is because the benchmark for success in schools is still focused on concepts. Learning so far tends to only hone aspects of remembering and understanding, not training students' skills in science learning. Optimal application of science process skills learning will be more interesting and create a positive impression that will be embedded in students until they grow up.

Science process skills are empirical and analytical skills carried out by scientists in understanding the universe. Patta Bundu (2006), With process skills, students can learn science according to what science experts do: observation, classification, inference, formulating hypotheses and conducting experiments. In the aspects of process skills, students are directed to understand science according to the methods used by scientists to find and develop their own facts and concepts so that the experience gained can be remembered in a relatively long time. In addition, the process will grow and develop attitudes and scientific values that can be used as a basis for solving problems encountered in everyday life. Therefore, children who master process skills will have the ability to discover, ask questions, collect data and make decisions in solving critical problems in various aspects of everyday life.

In blended learning, the activities in achieving these indicators still need to be seen and analyzed, what are the science process skills possessed by students? how to implement science process skills through blended learning? In this study, the author will raise several science materials in class IV for this research material. Based on the relevance of the problems described above, according to the author, it is necessary to extract information to conduct analysis in the school environment on the implementation of blended learning that occurs in students and teachers. Thus, the researcher intends to capture the research topic with the title: "Analysis of science process skills through blended learning in science subjects." 


\section{METHOD}

The type of research used in this research is qualitative research (Dalman et al., 2020a, 2020b; Kusuma \& Apriyanto, 2018; Subyantoro \& Apriyanto, 2020). The method used in this research is a case study. A case study is an intensive study of an individual or group of people who have experienced a particular case. In the case that occurred during the Covid 19 pandemic, the application of science process skills in science learning was not fully realized, so the scientific process received by students was less, and it was difficult for students to accept the material. This problem deserves to be researched because researchers want to know how science process skills can be carried out well so that it helps students absorb the material, especially during the covid 19 pandemic. So in this study, a case study was conducted to analyze the findings of problems that occurred in the application of skills. science process through blended learning of students at school. The source of data in this study is the subject from which the data can be obtained. This study's data sources were school principals, teachers, and fourth-grade students of MITQ Nurul Iman Sidoharjo Wonogiri as the research target from analyzing science process skills through blended learning.

The data collection technique used in this research is the triangulation technique, which is a technique that combines various data collection techniques and existing data sources. The triangulation Technique means collecting different data to get data from the same source. Triangulation techniques used in this study are interviews, observation, and documentation. The validity of the data in this study will be done by triangulation. Triangulation is a research technique for checking the validity of data that uses something other than the data for checking or as a comparison against the data. The triangulation technique that will be used in this research is triangulation of data or sources and triangulation of data collection methods. Data obtained from sources and then analyzed by researchers so as to produce conclusions. Data Analysis Techniques The data analysis technique that will be used in this research is an interactive analysis technique (model), namely qualitative data analysis which consists of three stages of activity. The three stages include data reduction, data presentation, and concluding along with data verification, Miles \& Huberman in Sutopo (2006).

\section{FINDINGS AND DISCUSSION}

\section{The process of implementing blended learning}

In meeting the learning needs of students during the COVID-19 pandemic, a learning model that can be applied during the current pandemic is needed. According to Dwiyanto (2020), learning that teachers and students can do easily and meet health protocol standards, one of which can be applied during this pandemic is blended learning. Based on the findings of the research conducted by researchers, MITQ Nurul Iman class IV has implemented a blended learning model. This can be seen from the planning, implementation and assessment carried out on the blended learning model in class IV during the covid-19 pandemic. 
From several observations that researchers have made, it can be seen that class IV teachers' ability to plan blended learning lessons is quite good. Teachers have good skills in preparing lessons. This is under the theory by Husamah which has been described. However, based on researchers' observations, teachers' ability to prepare teaching materials is still limited because the forms or teaching materials displayed are less varied. For example, when teachers use ppt as teaching materials, then for other learning content the teacher usually also uses the same ppt template so that students will be bored if they see the same display even though the material to be delivered is different. However, the teacher's skills have been assessed as quite good in preparing lessons. Because the fourth-grade teacher is not bored to continue learning using technology and keeps trying to prepare optimal blended learning.

Based on observations made by researchers several times, it is known that the application of the blended learning model in class IV has covered all components in blended learning, namely online learning carried out using online media such as zoom meetings, video calls via whatsapp and whatsapp groups. Students and teachers interact indirectly through these media and carry out learning with blended learning stages. The face-to-face learning component is carried out for deepening the material if there is material that has not been understood in online learning. In addition, face-to-face learning is also used for practical activities. Meanwhile, for the independent study component, students are asked to work on assignments usually picked up on Mondays or work on assignments given through online media. However, researchers combined online learning components with independent learning in this study. Because basically independent learning will lead to distance learning which will also involve the use of online media in the learning process. The results of these observations are in accordance with the opinion of Istiningsih and Hasbullah (2015), which states that the components of blended learning include:

a. Online learning is a learning environment that uses internet technology in accessing learning materials,

b. Face-to-face learning brings together teachers and students in one room to study,

c. Independent learning (individualized learning), namely students can learn independently by accessing information or learning materials online via the internet.

The application of the blended learning model in class IV uses a rotation model development model, in which the learning process is structured between face-to-face learning and online learning, which is carried out separately or has its own time. This is tailored to the needs of students in the class.

Assessment in blended learning, of course, includes face-to-face and online assessments. Bentri, Hidayati, et al.(2018) reveal several effective techniques that can be used to make online learning assessments that can be adapted to the blended learning model, namely as follows:

1) Provide regular assessment, communicate continuously with feedback to students as a means to add to the assessment in the learning itself,

2) Include dynamic interactions defined using group work, collaboration and high-level interaction through discussion, 
3) Modify traditional assessment tools such as essays, answer questions from discussions and projects that require demonstration of acquisition and problem-solving skills and

4) The use of alternative assessments such as performance appraisals, authentic assessments and the use of e-portfolios.

As has been done by the fourth-grade teacher, the assessment carried out generally includes an assessment of attitudes, knowledge and skills. Where the observations are done online and face to face. The teacher modifies the assessment tool to suit current conditions. Teachers use google forms to evaluate students' understanding. Then the teacher also conducts an assessment through the student's portfolio. The teacher observed the attitude assessment during face-to-face learning and online learning. In online learning the teacher will observe the behavior and responses of students during online learning. In addition, the teacher also has an attitude assessment journal that contains teacher notes on student attitudes both in face-to-face and online learning, which the teacher observes in detail. Meanwhile, the teacher observes the assessment of skills through practical activities carried out during face-to-face learning. The teacher also conducts performance assessments or product results that students have made on certain assignments.

\section{Implementation of science process skills through blended learning}

This study reported that the implementation of process skills in science learning requires an active process between teachers and students, especially during the covid 19 pandemic. In this case, teachers are active in planning and implementing process skills in science learning. The teacher creates a learning climate that seeks to provide student experiences in important ways to process and acquire knowledge. As Syaiful Sagala (2010), view, learning is a teacher activity programmed to help someone learn a new ability and or value. On the other hand, students are active in processing and acquiring science knowledge by implementing the process skills in learning. In accordance with the main objective of implementing learning activities in schools operationally is to teach students to be able to process and acquire knowledge, skills, and attitudes for themselves Dimyani and Mudjiono (2006) ith the presentation of science learning concepts and conditions during the COVID-19 pandemic, researchers will analyze science process skills through blended learning. The application of the blended learning model in class IV uses a rotation model development model, in which the learning process is structured between face-to-face learning and online learning which is carried out separately or has their own time.

Teacher planning in training process skills in science learning through blended learning includes providing opportunities for students to use process skills in the form of observing, communicating and concluding, preparing flexible techniques in the learning process, providing opportunities for students to discuss in small groups or classes, and conducting reviews. with students from the activities carried out. Implementation during learning is divided into 2 lessons, namely face-to-face and online. In face-to-face learning activities, the teacher provides learning in the form of practicum, discussion, experimentation and others. During online learning, using social media such as 
whatsapp groups, zoom meetings, and google meet, the teacher provides lessons such as theory, teacher center materials, and independent assignments.

From all learning, students have used process skills to observe, communicate, conclude, classify, and predict. Measuring skills have not been able to run due to time constraints. This is in line with the opinion of Abu Ahmadi and Munawar Sholeh (2005), children begin to analyze (analyze) their observations so that they know the properties of objects, humans and animals.

Aspects of observation, students carry out observation activities in each lesson. This is in line with what was revealed by Patta Bundu (2006) that the ability to observe is the ability to use the five senses to obtain data or information. The basic indicator of identifying objects is the dominant aspect in the observation. Students have not shown much ability in using all the senses, observation aids, qualitative observations and changes in an object because of the limitations of the object which is one of the causes.

Aspects of classification, not all materials use classification skills in the learning that is carried out. In classification ability, many students show it through the guidance of the teacher. The questions asked by the teacher provoke students to identify the properties of objects, group them into two groups and create branches from the group. Usman Samatowa (2006) states that grouping is a process of selecting objects or events based on similarities and differences in the nature or characteristics of an object or event. This also supports the opinion of Santrock (2010) which states that students already have provisions in classifying.

Aspects of communication, students have demonstrated ability in every indicator of communication skills. Students can describe objects and events carefully, provide an overview in such a way, communicate to others in writing or verbally, and experiment results with graphs, tables, data, and pictures. This is in accordance with the opinion that communication is the ability to convey the results of observations or knowledge possessed to others both orally and in writing, Patta Bundu (2006). From the results of observations, students convey the results both in writing and orally from the observations made. In writing, students work on student worksheets contained in the handbook.

Aspects of prediction, In predictive ability, students show it through guidance from the teacher in diagnosing and conducting tests to test predictions. Prediction is submitting possible results from an experiment, Trianto (2010). When conducting sound propagation experiments, students are able to make predictions about possible changes in sound propagation from changes in student activities.

Aspects of making conclusions, students have shown most of the indicators. Many students show it through the guidance of the teacher. The inference is drawing conclusions and explanations from observations, Patta Bundu (2006) students are able to explain the relationship between objects and observed events, make conclusions based on facts in the form of experimental results and observations made and then express them through reasoned opinions.

Aspects of measuring, students have not carried out measuring activities. Measuring skills are important for making quantitative observations, comparing, and classifying objects and communicating effectively. 


\section{CONCLUSION}

The blended learning model is considered to be an alternative or learning solution during the COVID-19 pandemic. Learning planning is arranged systematically by the teacher. Starting from preparing learning tools such as Prota, Promes, Syllabus, RPP to LKPD in accordance with blended learning. The teacher also arranges the learning schedule between online and face-to-face learning. Even teachers also prepare special learning media for online learning such as learning videos from youtube and power point. The teacher always checks the completeness of the student's health protocol during face-to-face learning. The implementation of learning carried out in class IV is in accordance with the syntax of blended learning.

Teacher planning in training process skills in science learning includes providing opportunities for students to use process skills in the form of observing, communicating and concluding, preparing flexible techniques in the learning process, providing opportunities for students to discuss in small groups or classes, and conducting reviews with students. of the activities carried out. The implementation of learning in training process skills in learning that has been carried out by teachers, namely; 1) provide opportunities for students to use process skills in the form of observing, communicating, inferring, classifying and predicting, 2) using flexible techniques in the learning process, and 3) providing opportunities for students to discuss in small groups or classes. Process skills shown by students during the learning process from high quality to low quality in the form of observing, communicating, concluding, classifying and predicting. The skills that are often shown by students are in the form of observing and communicating skills.

\section{REFERENCES}

Ahmadi, Abu, Sholeh, Munawar. (2005). Psikologi Perkembangan, Jakarta: PT. Rineka Cipta.

Abdul Aziz. (2012). Pengertian, Tujuan, Fungsi dan Manfaat Hasil Belajar. (Tersedia diakses tanggal 2 April 2015 Jam 7.29)

Bentri, A. (2017). Mastery of primary school teacher pedagogy competency incurriculum 2013 implementation in Indonesia. Couns-Edu: The International Journal of Counseling and Education, Vol. 2, No. 2, pp. 78- 84.

Dalman, Hesti, \& Apriyanto, S. (2020a). Conversational implicature: A pragmatic study of "our conversation" in learning at university. International Journal of Psychosocial Rehabilitation, 24(8),

4332-4340. https://doi.org/10.37200/IJPR/V24I8/PR280450

Dalman, Hesti, \& Apriyanto, S. (2020b). Conversational implicature: A pragmatic study of "our conversation" in learning at university. International Journal of Psychosocial Rehabilitation, 24(8), 4332-4340.

Destika, V. (2022). Effectiveness of Match Technique to Improve Students' Vocabulary Mastery based on Gender. Journal Corner of Education, Linguistics, and Literature, 1(3), 168-175. https://doi.org/10.54012/jcell.v1i3.33

Hasbullah dan Istiningsih Siti. (2015). Blended Learning, Trend Strategi Pembelajaran Masa Depan. dalam Jurnal Elemea, Vol. 1, No. 1, 
Herlisya, D., \& Wiratno, P. (2022). Having Good Speaking English through Tik Tok Application. Journal Corner of Education, Linguistics, and Literature, 1(3), 191-198. https://doi.org/10.54012/jcell.v1i3.35

Kusuma, H. A., \& Apriyanto, S. (2018). Strategy on Developing English Learning Material for Specific Purposes. IJECA (International Journal of Education and Curriculum Application), 1(3), 39. https://doi.org/10.31764/ijeca.v1i3.2144

Mahmud, Dimyati dan Mudjiono. (2006). Belajar dan pembelajaran, Jakarta: Rineka Cipta.

Miles, M.B, Huberman,A.M, dan Saldana,J. (2014). Qualitative Data Analysis, A Methods Sourcebook, Edition 3. USA: Sage Publications. Terjemahan Tjetjep Rohindi Rohidi, UI-Press.

Nurchurifiani, E., \& Zulianti, H. (2021). Use of Problem-Based Digital Comics in the Era of Disruption as an Increasing Effort Critical Thinking Skills and Learning Achievement. Journal Corner of Education, Linguistics, and Literature (JCELL), 1(1), 1-7. https://doi.org/https://doi.org/10.54012/jcell.v1i1.5

Patta Bundu. (2006). Penilaian Keterampilan Proses dan Sikap Ilmiah dalam Pembelajaran Sains-SD. Jakarta: DEPDIKNAS.

Sagala, Syaiful. (2010). Supervisi Pembelajaran dalam Profesi Pendidikan. Bandung: Alfabeta.

Sagita, I. K. (2021a). Applying Conversation Method and Self-Confidence and Its Effect to Learning Achievement. Journal Corner of Education, Linguistics, and Literature, 1(2), 122-131. https://doi.org/10.54012/jcell.v1i2.11

Sagita, I. K. (2021b). Applying Conversation Method and Self-Confidence and Its Effect to Learning Achievement. Journal Corner of Education, Linguistics, and Literature (JCELL), 1(2), 122-131. https://doi.org/10.54012/jcell.v1i2.11

Santrock, J.W. (2010). Remaja (Edisi Kesebelas). Jakarta: Erlangga

Sitohang, G. J., Sumiati, A., \& Susanti, S. (2021). Effect of Problem Based Instruction Model Based on Learning Video and Educational Games Media on the Self Efficacy of Students of Class X SMK N 17 Jakarta. Journal Corner of Education, Linguistics, and Literature, 1(2), 106-113. https://doi.org/10.54012/jcell.v1i2.9

Subyantoro, S., \& Apriyanto, S. (2020). Impoliteness in Indonesian Language Hate Speech on Social Media Contained in the Instagram Account. Journal of Advances in Linguistics, 11, 36-46. https://doi.org/10.24297/jal.v11i.8655

Sulastri, S., YL, S., \& Nurhasanah, N. (2022). Utilization of Educational Games in the Implementation of Strengthening Character Education. Journal Corner of Education, Linguistics, and Literature, 1(3), 148-156. https://doi.org/10.54012/jcell.v1i3.32

Sutopo Ariesto. (2012). Teknologi Informasi dan Komunikasi dalam Pendidikan. Yogyakarta: Graha Ilmu.

Usman Samatowa. (2006). Bagaimana Membelajarkan IPA di Sekolah Dasar. Jakarta: Depdiknas Dirjen Pendidikan Tinggi Direktorat Ketenagaan. 